\title{
Runoff and erosion as affected by tillage system and polyacrylamide in two sandy loam soils differing in silt and clay contents in semi-arid regions
}

\author{
Nidal H. Abu-Hamdeh ${ }^{\text {** Saleh M. Ismail }}{ }^{2}$, Samir G. Al-Solaimani ${ }^{3}$ and Randa I. Hatamleh ${ }^{4}$ \\ ${ }^{1}$ King Abdulaziz University, Faculty of Engineering, Mechanical Engineering Department, Jeddah, Saudi Arabia \\ ${ }^{2}$ King Abdulaziz University, Faculty of Meteorology, Environment and Arid Land Agriculture, Jeddah, Saudi Arabia \\ ${ }^{3}$ King Abdulaziz University, Faculty of Meteorology, Environment and Arid Land Agriculture, Jeddah, Saudi Arabia \\ ${ }^{4}$ Yarmouk University, Faculty of Engineering, Civil Engineering Department, Irbid-Jordan
}

\begin{abstract}
This study aims to investigate the effect of three tillage practices and the effect of polyacrylamide application rate on surface runoff and erosion of sandy loam soils differing in silt and clay contents. Field experiments in splitsplit plot with four replications were carried out in two different locations; location A that consists of $25.2 \%$ silt plus clay and location B which consists of $38.5 \%$ silt plus clay. Three tillage practices were investigated; no-tillage (NT), mouldboard ploughing with rotor tiller (CT1), and chisel ploughing with disk harrow (CT2). Three polyacrylamide (PAM) rates were implemented in each tillage system; 0,10 and $20 \mathrm{~kg} \mathrm{ha}^{-1}$. The experiment was conducted during December 2015 to April 2017 and wheat was sown for the two seasons. Results showed that the CT1 and CT2 treatments reduced runoff by $15.3 \%$ and $50.0 \%$, respectively in location A and by $6.4 \%$ and $13.8 \%$, respectively, in location $B$ compared to the NT treatment. Applying 10 and $20 \mathrm{~kg} \mathrm{ha}^{-1}$ of PAM decreased runoff by $9.5 \%$ and $22 \%$, respectively in location $A$ and by $4.5 \%$ and $12 \%$, respectively in location B compared to the $0 \mathrm{~kg}$ ha ${ }^{1}$ PAM treatment. Applying 10 and $20 \mathrm{~kg} \mathrm{ha}^{-1}$ PAM reduced soil erosion by $19 \%$ and $28 \%$, respectively, in location A and by $26 \%$ and $33 \%$, respectively in location B compared to the $0 \mathrm{~kg} \mathrm{ha}^{-1}$ PAM application rate. Comparing the effect of tillage practices in location (A), the CT1 increased soil erosion by $16.5 \%$ and $46.5 \%$ compared with the NT and CT2 treatments, respectively. Comparing the effect of tillage practices in location $(B)$, the CT1 increased soil erosion by $38.6 \%$ and $75.6 \%$ compared to the NT and CT2, respectively.
\end{abstract}

Keywords: Chisel ploughing, mouldboard ploughing, no-tillage, surface runoff, erosion

\section{Introduction}

The major tillage method to be used is the conventional tillage (CT) because it is effective for preparing the seedbed, incorporating manure and residue, compaction lessening and weed control. However, possible disadvantages of CT are soil tilth destruction, enhanced soil crusting, runoff and erosion, high costs of labour, energy and equipment (Das et al., 2014; Kuotsu et al., 2014).

Conservation of soil and water is the most significant in avoiding the degradation of land and production loss in the Mediterranean countries. The productivity of rain-fed farming may increase by implementation of nonconventional management, by improving the traditional soil and water conservation techniques and by better design of water harvesting systems (Rockström et al., 2009; Baudron et al., 2012; Palm et al., 2013; Pittelkow et al., 2014). Conservation tillage increases soil water storage by improving water infiltration, reducing surface runoff and decreasing evaporation (Moraes et al., 2013). It conserves water within the root zone, minimizes soil erosion, and improves agronomic productivity (Durr et al., 2001). El Atta et al. (2013) investigated the efficiency of rainwater in water harvesting (quadrangular, terraces, semi-circular bunds) in the southwestern of Saudi Arabia. They found that these structures significantly increased infiltration rate, soil porosity and moisture content. Hence, runoff and soil erosion were significantly reduced.

Several research studies investigated the effect of tillage practices on infiltration of rain and their effects on erosion and runoff from soil. Based on laboratory studies, no-till management improved soil and water conservation in light textured soils, (Conant et al., 2011; Kahlon et al., 2013; Shekhawat et al., 2016; Linhua et al. 2017). No-till has also been shown to provide substantial water conservation, energy and ecological benefits (Ngigi et al., 2006; Morris et al., 2010; VanWie et al., 2013). On the other hand, many other studies showed no beneficial effect of NT on the hydraulic properties of the soils (Shukla et al. 2003). Based on field studies, results revealed that the beneficial effect of no-till and conservation tillage on some

*Email: nabuhamdeh@kau.edu.sa 
soil physical properties was not always demonstrated (Fuentes et al., 2009; Gozubuyuk et al., 2014; Salem et al., 2015; da Costa and Crusciol, 2016).

Improving rain water penetration and controlling runoff and erosion are expected to benefit from the application of Polyacrylamide (PAM) on the soil surface (Mamedov et al., 2010; Lee et al., 2015). Polyacrylamide (PAM) has been recognized to enhance aggregate stability and soil structure, increase infiltration rate and soil water retention, and an efficient mean to decrease runoff and soil erosion (Green and Stott, 2001; Peterson et al., 2002; Graber et al., 2006; Sojka et al. 2007; Lee et al. 2010). Yu et al. (2003) studied the influence of surface enhancement of silt loam and sandy clay during simulated rainstorms by granular PAM (10 and $20 \mathrm{~kg} \mathrm{ha}^{-1}$ ) on soil erosion and surface runoff. Spreading dry PAM decreased erosion to $30 \%$ of the control and enlarged the final infiltration rate of the two soils by four times. Sojka et al. (2007) stated that PAM bonds fragment and produce bigger aggregates and thus avoid the formation of crust on the soil surface, hence decreasing erosion. It also modifies the soil chemical, biological, and physical properties, thus enhancing root and water penetration, aeration, and erosion resistance. The effectiveness of PAM is likely to be larger in soils with high clay content for the greater amount of charged bonding sites (Lee et al., 2010). Enhancement outcomes of PAM last over extended time because of its $9.8 \%$ per year decomposition rate and it is the most unaffected by microbial dissolution among other normally utilized polymers (Lentz and Bjorneberg, 2003; Sojka et al., 2007).

Our hypothetical concept in this study that sustainable rain-fed agriculture is better achieved under farming practices that are carefully designed in accordance with soil type. Therefore, the objectives of this research were to study the effect of no-tillage (NT) compared to the conventional tillage (CT) and to analyse the effect of PAM application rate on surface runoff and erosion of sandy loam soils differing in silt and clay contents.

\section{Materials and Methods}

\section{Location, design and layout of the field experiment}

This research study was conducted at the Agriculture Experimental Station of King Abdulaziz University (KAU) which is located at Hada Alsham, $110 \mathrm{~km}$ northeast of Jeddah city $\left.21^{\circ} 48^{\prime} 3^{\prime \prime} \mathrm{N}, 39^{\circ} 43^{\prime} 25^{\prime \prime} \mathrm{E}\right), \mathrm{KSA}$. The period of the experiment was extended from December $1^{\text {st }}, 2015$ till end of April of 2017. Within this period the soil of both locations (500 $\mathrm{m}$ distance between the two locations) was cultivated for two consecutive seasons. The design used in this research study was a split-split plot design with four replications. Two soil locations were taken as the main plot. The two locations have not been cultivated for many years and they were different in clay and silt contents. Location A consists of $74.8 \%$ sand, $15.5 \%$ silt, $9.7 \%$ clay while location B consists of $61.5 \%$ sand, $25.7 \%$ silt, $12.8 \%$ clay.Three tillage practices were taken as the sub main plots; CT1 stands for mouldboard ploughing with rotor tiller, NT stands for no-tillage, and CT2 stands for chisel ploughing followed by disk harrowing.

The second level of plots (sub-sub main plots), each with an area of $18 \mathrm{~m}^{2}$, were three granular rates of PAM application $\left(0,10\right.$ and $\left.20 \mathrm{~kg} \mathrm{ha}^{-1}\right)$. In each experimental site a total area of $1560 \mathrm{~m}^{2}$ was identified to apply all treatments that comply with the statistical design explained previously. The investigated area had a gentle slope of about $0.01 \%$. No PAM was applied onto the surface of soil in the control PAM plots $\left(0 \mathrm{~kg} \mathrm{ha}^{-1}\right)$ in all tillage systems. In the other treatments, PAM was added to the whole surface area of each plot and mixed manually with the upper layer of the soil. The only exception was in the NT treatment where PAM was thrown onto the topsoil. Application of PAM was done for one time before the starting of the experiment. After applying tillage systems and PAM rates, wheat seed was sown in all treatments at November 21, 2015 and 2016 in rows spaced apart at $20 \mathrm{~cm}$ by a seed drill that is $10 \mathrm{~cm}-$ wide at a seeding rate $130 \mathrm{~kg} \mathrm{ha}^{-1}$. The recommended cultural practices for wheat crop were followed until the harvesting.

\section{Irrigation system and network}

Sprinkler irrigation system was installed in each location to apply irrigation water as in natural rain fall. Under the current study, 2045-PJ Maxi-Bird TM rotator was used. The system's inlet pressure was 2.5 bars. The rotator's radius was adjusted to be $11.7 \mathrm{~m}$ with a $0.76 \mathrm{~m}^{3} / \mathrm{h}$ as maximum discharge and precipitation rate of $11 \mathrm{~mm} / \mathrm{h}$. After installation, the system distribution uniformity was measured and found to be about $90 \%$ in both locations. The daily crop water requirement was calculated based on metrological weather condition of the experimental area and crop growth stages using CROPWAT model. Sprinkler irrigation was applied three times during the growing season. Detailed analysis of soil physical and chemical properties and irrigation water in both experimental locations is presented in Table 1. The experimental site's metrological data throughout the period of the field work is presented in Table 2.

\section{Measuring runoff and soil erosion}

When water supply either by irrigation or rainfall is higher than soil infiltration rate, part of the supplied water moves horizontal as runoff. The amount of runoff depends 
Table 1: Initial physical and chemical soil analyses before the starting of the experiment for experimental soil and irrigation water

\begin{tabular}{lll}
\hline & \multicolumn{1}{c}{ Experimental soil } & \\
\hline Variable & Location $(\mathbf{A})$ & Location $(\mathbf{B})$ \\
\hline Particle size analysis & & \\
Clay \% & 9.7 & 12.8 \\
Silt \% & 15.5 & 25.7 \\
Sand \% & 74.8 & 61.5 \\
Texture class & Sandy loam & Sandy loam \\
\hline & Penetration resistance & Slight compacted \\
\hline Layer 0-15 & Moderate compacted & compacted \\
Layer 15-30 & compacted & compacted \\
Layer 30-45 & compacted & 1.71 \\
Bulk density $\left(\mathrm{g} / \mathrm{cm}^{3}\right)$ & 1.87 & 35.4 \\
Air porosity $(\%)$ & 29.4 & 7.0 \\
infiltration rate $(\mathrm{cm} /$ hour $)$ & 16.0 & $1.10 \%$ \\
Organic matter $(\%)$ & $0.65 \%$ & \\
\hline
\end{tabular}

Table 2: Metrological data of the experimental site during the period of the field work

\begin{tabular}{|c|c|c|c|c|c|c|}
\hline Year & Month & $\begin{array}{c}\text { Minimum temperature } \\
{ }^{\circ} \mathrm{C}\end{array}$ & $\begin{array}{c}\text { Maximum temperature } \\
{ }^{\circ} \mathrm{C}\end{array}$ & $\begin{array}{c}\text { Relative humidity } \\
\%\end{array}$ & $\begin{array}{l}\text { Wind speed } \\
\text { km/day }\end{array}$ & $\begin{array}{c}\text { Rainfall } \\
\text { mm }\end{array}$ \\
\hline \multirow{2}{*}{2015} & November & 18.0 & 37.0 & 64.9 & 197 & 5.2 \\
\hline & December & 12.5 & 31.7 & 68.4 & 284 & 4.7 \\
\hline \multirow{12}{*}{2016} & January & 10.9 & 30.4 & 69.8 & 187 & 2.1 \\
\hline & February & 11.0 & 36.0 & 58.7 & 226 & 7.0 \\
\hline & March & 15.6 & 40.0 & 58.9 & 181 & 0.0 \\
\hline & April & 15.7 & 39.7 & 55.3 & 208 & 34.5 \\
\hline & May & 22.2 & 44.9 & 45.6 & 162 & 9.51 \\
\hline & June & 22.8 & 45.5 & 35.2 & 183 & 0.0 \\
\hline & July & 23.4 & 42.5 & 41.3 & 197 & 0.0 \\
\hline & August & 23.4 & 43.3 & 55.5 & 178 & 0.7 \\
\hline & September & 22.7 & 43.3 & 58.6 & 160 & 5.7 \\
\hline & October & 20.6 & 41.0 & 59.5 & 134 & 2.0 \\
\hline & November & 18.0 & 36.7 & 65.0 & 143 & 0.1 \\
\hline & December & 14.5 & 32.8 & 71.6 & 138 & 1.6 \\
\hline \multirow{3}{*}{2017} & January & 13.2 & 33.4 & 68.0 & 147 & 0.2 \\
\hline & February & 15.6 & 33.0 & 55.5 & 240 & 0.3 \\
\hline & March & 25.0 & 33.4 & 63.5 & 214 & 0.0 \\
\hline
\end{tabular}
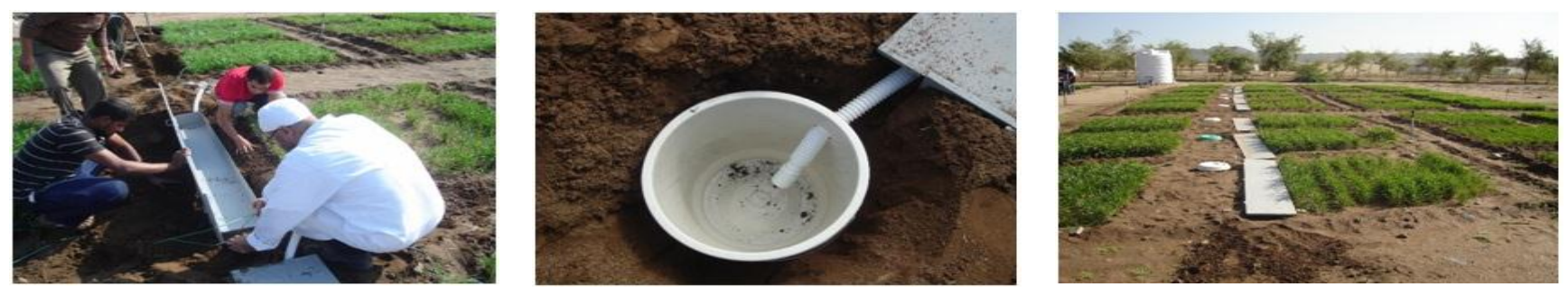

Figure 1: Runoff and erosion unit installation and operation in the field

on the soil infiltration rate and on the amount of water supply. In this study, runoff and erosion collection devices were installed in both experimental fields at the beginning of December 2015 and kept in their locations until the end of April 2017. During that period, runoff was collected and measured eight times. Five of these measurements were collected after natural rainfall while the remaining three measurements were collected when the fields were irrigated by sprinkler irrigation system that was used in the experiments as a supplementary irrigation method. 
To reveal the effects of the various treatments on soil predisposition to erosion and runoff, each plot in the two experimental sites was enclosed by a galvanized plate of iron which was fixed at the end of the plot to interrupt the runoff and send it into a basin. The collecting plate was projecting $2 \mathrm{~cm}$ above the soil surface and implanted $15 \mathrm{~cm}$ into the soil surface. In order to prevent direct rainfall entry into the basins they were enclosed with lids. The basin conveyed the runoff into tanks each with $0.1 \mathrm{~m}^{3}$ volume via a siphon pipe (Figure 1). After each storm, the volume of water was recorded then the tanks were emptied. Before emptying each tank, the content of the tank was blended completely and three sub samples (100 mL each sample) were taken to determine soil erosion by weighing the quantity of remaining sediment after oven drying these samples at $105{ }^{\circ} \mathrm{C}$. These three sub samples represent three replicates of the measurements. Once the weight of soil particles in the $100 \mathrm{~mL}$ sample was obtained it was used to obtain the weight of soil in the runoff volume of each treatment that was collected after each storm, and then this was converted to $\mathrm{kg}$ of soil per hectare.

\section{Statistical analysis}

The obtained data were statistically analysed through analysis of variance procedures to determine the significance of the treatments and the interactions. LSD test was used to compare the means after applying the statistical analysis assumptions according to El-Nakhlawy (2010) using SAS (2006).

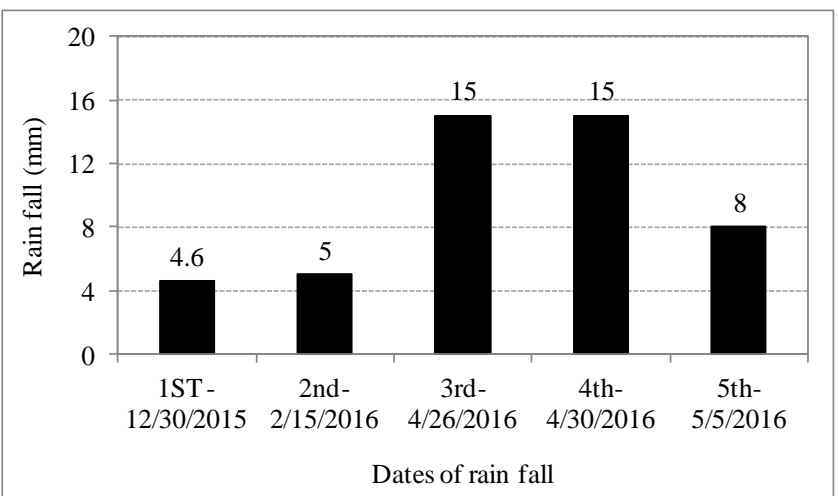

Figure 2: Amounts and dates of rainfall on the experimental area during the period from December 1, 2015 till April 30, 2017

\section{Results and Discussion}

\section{Surface runoff}

When water supply either by irrigation or rainfall is higher than soil infiltration rate, part of the supplied water moves on surface horizontally along the slope as runoff. The amount of the natural rainfall occurred in each of the five times of the measurements is shown in Figure 2. The highest rainfall occurred in April 26 and 30 of 2016 and the second highest rainfall occurred in May 5, 2016. At the time of May measurement wheat crop was harvested and the soil was bare. The next highest rainfall occurred in February 15, 2016 where the soil was still covered by wheat crop. The least rainfall occurred in December 30, 2015 .

For better visualization of the influences of tillage methods and rate of PAM application on surface runoff, results of cumulative runoff measured during the whole period of this study are presented in Figure 3. When averaged across all treatments, runoff in the second location (B) was significantly greater than its value in the first location (A) by about $48 \%$. The results are logical and expected because the soil texture in the first location (A) was lighter than that of the second location (B). The sand content was $74.8 \%$ in location A while it was $61.5 \%$ in location B. In light textured soil, infiltration rate and saturated hydraulic conductivity increased by increasing sand content due to the presence of large pores. As a result, more water infiltrated and less water runoff in location A when compared with location B.

Obviously, tillage system significantly affected runoff in both locations. The highest runoff was measured in the NT treatment followed by the CT1 treatment while the least runoff was recorded in the CT2 treatment. The results could be attributed to the reduction in infiltration rate of the NT treatment compared to the $\mathrm{CT} 1$ and $\mathrm{CT} 2$ treatments. Decreasing infiltration rate increased the horizontal movement of water which resulted in higher runoff in the NT treatment compared to the other two treatments. Soil macropores have been investigated widely; the results are not consistent (Bhattacharyya et al., 2006; Daraghmeh et al., 2009). In some cases, even lower than that under tillage treatment, as in deeply tilled soils, intensive tilled soil pores are formed primarily by the tillage tool. Similarly, Zhang et al. (2016) concluded that No-tillage although increased water conducting macropores but did not increase hydraulic conductivity. However, our results are contradictory with soil macroporosity under no-tillage is usually higher (Bodhinayake and Si, 2004; Coquet et al., 2005; Moret and Arrúe, 2007) under tilled soil. As indicated in Figure 3 and 4 , soil runoff was higher in the CT1 treatment than in the CT2 treatment. Soil ploughing might destruct soil aggregates and pore system distribution in soil which is responsible for the filtration of water in soil (Smith et al., 2007). Because the destruction results from mouldboard ploughing was higher than that resulted from chisel ploughing, water infiltration was decreased and runoff was increased in the CT1 treatment than in CT2 treatment. Numerically, the CT1 and CT2 reduced runoff by about 

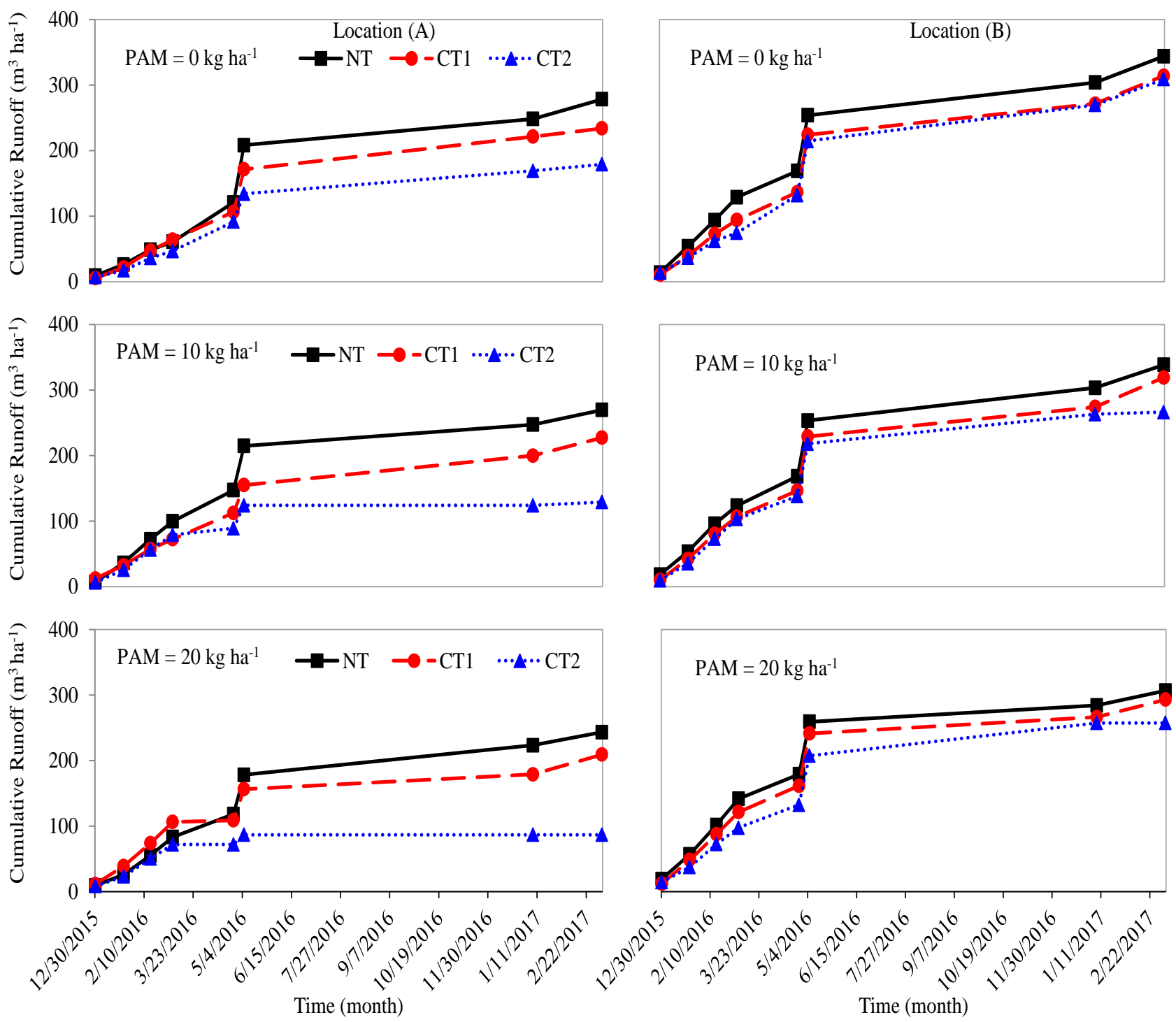

Figure 3: Cumulative runoff $\mathrm{m}^{3} \mathrm{ha}^{-1}$ from the experimental soil as affected by locations, tillage systems and PAM rates for wheat crop along the growth period of the two seasons of 2015/16 and2016/17. Location A: (clay and silt $=25.2 \%$ ), Location B: $($ clay and silt $=38.5 \%)$, NT: no tillage, CT1: mouldboard ploughing with rotor tiller, CT2: chisel ploughing with disk harrow, PAM: polyacrylamide polymer

$15.3 \%$ and $50.0 \%$, respectively, in location A compared with that of the NT treatment. In location B, the CT1 and CT2 treatments reduced runoff by about $6.4 \%$ and $13.8 \%$, respectively, compared to the runoff of the NT treatment.

As for the effect of PAM application rate on runoff, increasing PAM application rate gradually and significantly decreased runoff in all tillage treatments in both locations as shown in Figure 4 which presents the total runoff results as influenced by tillage method, locations, and PAM application rates during the whole growth period of the two seasons. The results might be due to the improvement in soil infiltration rate because adding PAM was found to be effective in decreasing erosion and increasing infiltration (Yu et al., 2003).

The sharp increase in runoff values at the $5^{\text {th }}$ and $6^{\text {th }}$ measurements as shown in Figure 3 might be due to the large amount of the rainfall immediately before the measurements were taken as clearly indicated by the amounts of rainfall on the experimental area (presented in Figure 2). Increasing water supply for longer time decreases infiltration rate. Firstly, water enters, or infiltrates quickly but after certain time the infiltration decreases to a constant 
rate while rainfall continues which resulted in an increase in runoff (Benham et al., 2003). In short, Application of PAM decreased runoff in both locations. The reductions in locations A were about $9.5 \%$ and $22 \%$ in the 10 and $20 \mathrm{~kg}$ $\mathrm{ha}^{-1}$ PAM application rate treatments compared with the 0 $\mathrm{kg} \mathrm{ha}{ }^{-1}$ PAM application rate treatment. However, the reductions in location $\mathrm{B}$ were $4.5 \%$ and $12 \%$ in the 10 and $20 \mathrm{~kg} \mathrm{ha}^{-1}$ PAM treatments compared with the $0 \mathrm{~kg} \mathrm{ha}^{-1}$ treatment.

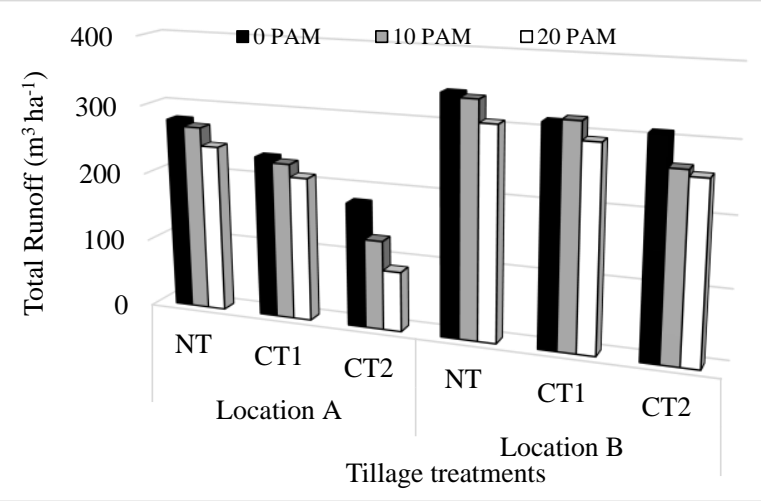

Figure 4: Total runoff in $\mathrm{m}^{3} \mathrm{ha}^{-1}$ from the experimental soil as affected by locations, tillage systems and PAM rates for wheat crop during the whole growth period of the two seasons. Location A: (clay and silt $=\mathbf{2 5 . 2 \%})$, Location B: $($ clay and silt $=38.5 \%$ ), NT: no tillage, CT1: mouldboard ploughing with rotor tiller, CT2: chisel ploughing with disk harrow, PAM: polyacrylamide polymer $($ LSD $0.05=32)$

\section{Soil erosion}

Soil erosion was measured in same plots used to measure runoff as explained in methodology section. The results of the cumulative erosion during the period of the field experiment (beginning of December 2015 till the end of April 2017) as affected by tillage system and PAM application rates are presented in Figure 5. Results clearly show that soil erosion in location A was significantly higher by about $52.5 \%$ than that in location B. This could be related to the higher percentage of fine particles in location B compared to location A. The presence of fine particles might encourage soil granulation and stabilized soil aggregates in the second location (B) more than it did in the first location (A). Increasing the number and size of aggregates might decrease settling time of particles suspended in runoff water, consequently decrease soil erosion (McLaughlin and Bartholomew, 2007).

Tillage system shows significant very clear effect on soil erosion. The highest eroded sediment was recorded in the CT1 followed by the NT and CT2, respectively, in both locations. Ploughing loosen the soil particles in the surface soil layer especially in the CT1 treatment. Without using cohesive material to join the soil particle after ploughing, the chance for sediment transport with irrigation water or raindrops increased. Tillage disrupts soil aggregates causing break down and reduce the aggregate size (Alvaro-Fuentes et al., 2008). Soil erosion in the NT treatment was lower than in the CT1 treatment. The results could be explained by the stability of the structure in the NT which reduced sedimentation compared to the CT1 treatment. On the other hand, soil erosion in the NT treatment was higher than in the CT2 treatment. This is because of the greater runoff in the NT compared to the CT2 treatment. As runoff increases, its ability to load soil sediment increases and results in higher erosion. The least soil erosion was recorded in the CT2 treatment which could be explained by knowing that the lowest runoff values were measured in the CT2 treatment among other tillage treatments. Mohamadi and Kavian (2015) stated that decreasing runoff might be met by low soil erosion since the water is the main source to erode and transport loosen soil. To summarize, the CT1 increased soil erosion by $16.5 \%$ and $46.5 \%$ compared with NT and CT2, respectively. The CT2 reduced soil erosion by $20.5 \%$ compared with the NT treatment. In location B, the CT1 increased soil erosion by about $38.6 \%$ and $75.6 \%$ compared with the NT and CT2, respectively. The CT2 reduced soil erosion by about $21 \%$ compared with NT treatment.

Applying PAM revealed significant great influence on soil erosion. The highest eroded soil was found in the $0 \mathrm{~kg}$ $\mathrm{ha}^{-1}$ PAM treatment. Applying $10 \mathrm{~kg} \mathrm{ha}^{-1}$ of PAM resulted in sharp decrease in soil erosion in both locations but the reduction was pronounced in the first location (A) more than it is in the second location (B) especially in the NT and CT1 treatments. Increasing PAM application rate to $20 \mathrm{~kg} \mathrm{ha}^{-1}$ increased the reduction of soil erosion but the reduction in soil erosion as PAM rate increased from 10 to $20 \mathrm{~kg} \mathrm{ha}^{-1}$ was less than the reduction resulted from increasing PAM rate from 0 to $10 \mathrm{~kg} \mathrm{ha}^{-1}$. Figure 6 shows the total eroded soil over the whole period of the experiments. It shows that the highest eroded soil was in $0 \mathrm{~kg} \mathrm{ha}^{-1} \mathrm{PAM}$ application rate followed by the 10 and least with $20 \mathrm{~kg} \mathrm{ha}^{-1}$ application rate, respectively. PAM is considered as a cohesive material so its presence in the soil encourages granulation and soil aggregation (Sojka et al., 2006; Mamedov et al., 2010). Increasing structure stability and aggregate in soils might lead to stabilize the surface of the soil versus shear-inducing detachment, decreasing soil susceptibility to seal formation, runoff generation and soil erosion. Application of little quantity of mild to high molecular weight of PAM has efficiently seal formation in soils from semiarid and arid zones and controlled aggregate breakdown (Bjorneberg and 

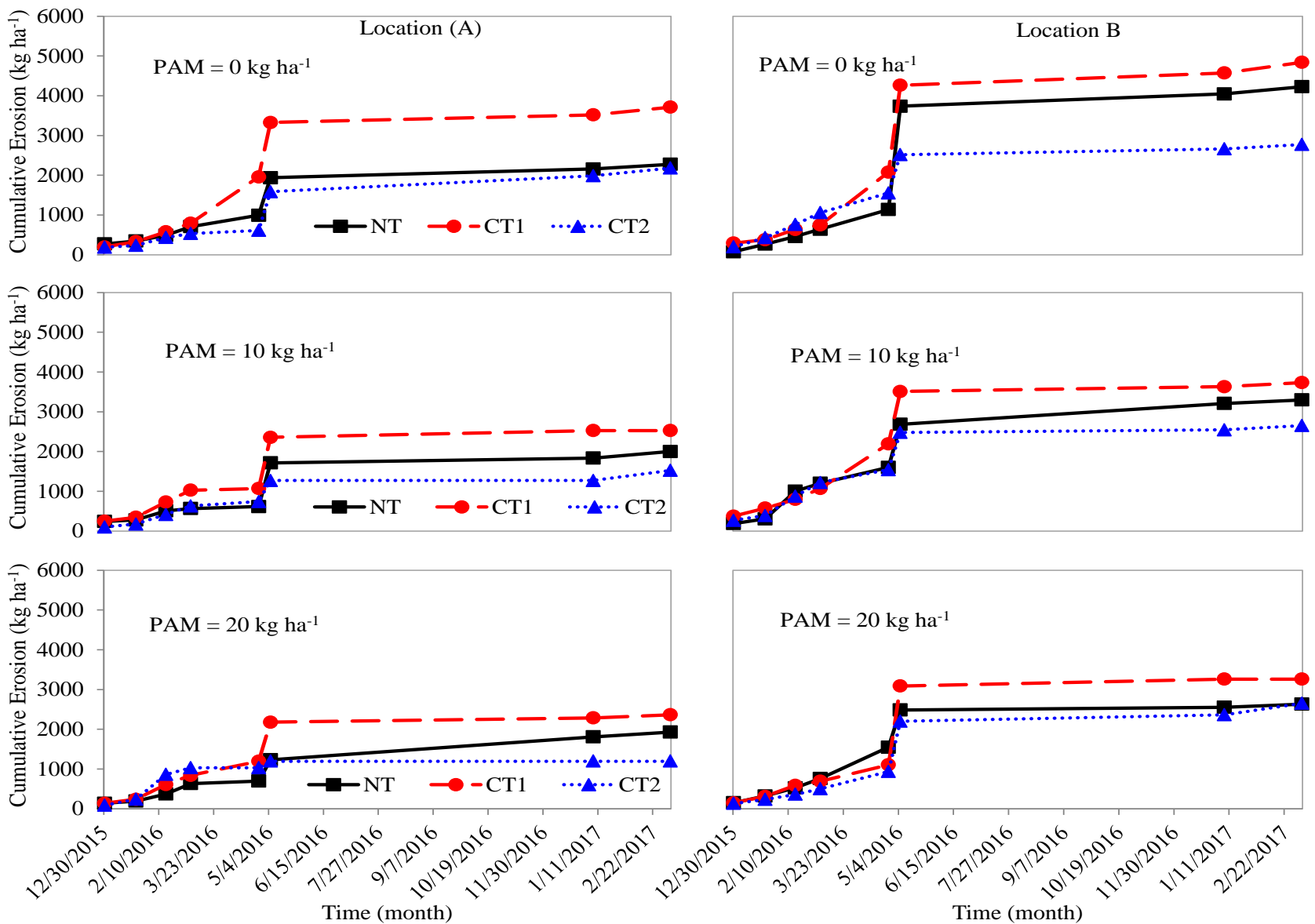

Figure 5: Cumulative soil erosion in $\mathrm{kg} \mathrm{ha}^{-1}$ from the experimental area as affected by locations, tillage systems and PAM rates for wheat crop along the growth period of the two growing season of 2015/16 and 2016/17. Location A: clay and silt $=25.2 \%$, Location B: clay and silt $=38.5 \%$, NT: no tillage, CT1: mouldboard ploughing with rotor tiller, CT2: chisel ploughing with disk harrow, PAM: polyacrylamide polymer

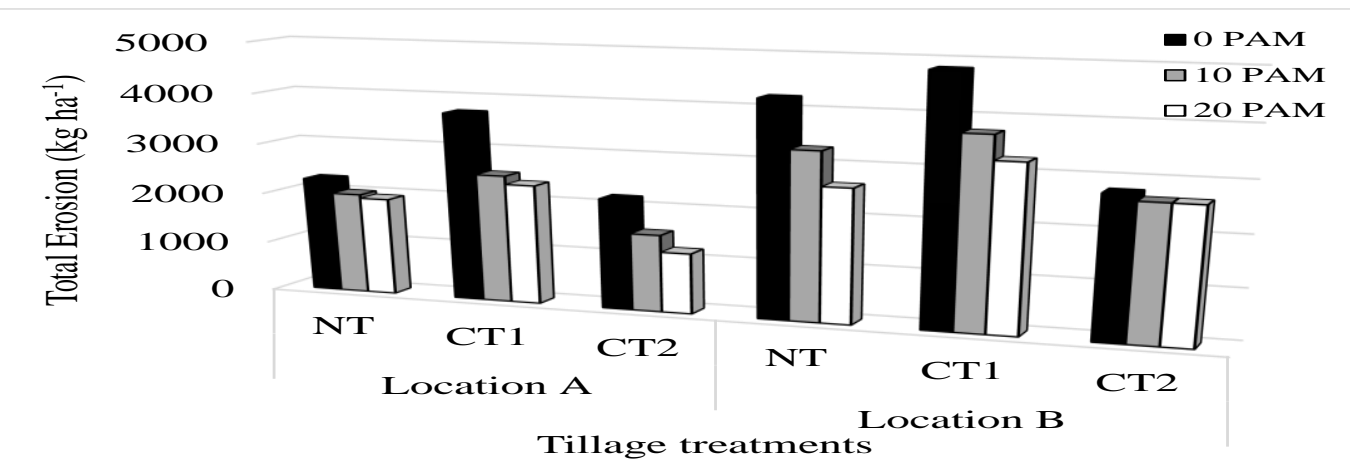

Figure 6: Total soil erosion in $\mathrm{kg} \mathrm{ha}^{-1}$ from the experimental soil as affected by locations, tillage systems and PAM rates for wheat crop during the whole growth period of the two seasons. Location A: (clay and silt = 25.2\%), Location B: (clay and silt $=38.5 \%$ ), NT: no tillage, CT1: mouldboard ploughing with rotor tiller, CT2: chisel ploughing with disk harrow, PAM: polyacrylamide polymer (LSD $0.05=118$ )

Aase, 2000). Yu et al. (2003) reported similar results. They stated that spreading dry PAM decreased erosion by $30 \%$ compared to control in sandy loam and sandy soils. Moreover, constitution of soil aggregates as a result of PAM 
application might increase the size and thus decrease settling time of particles suspended in runoff water (Green et al., 2004; Petersen et al., 2007; McLaughlin and Bartholomew, 2007). To recap, increasing PAM rates decreased soil erosion in both locations. Applying 10 and 20 $\mathrm{kg} \mathrm{ha}^{-1}$ PAM reduced soil erosion by $19 \%$ and $28 \%$ compared to the $0 \mathrm{~kg} \mathrm{ha}^{-1} \mathrm{PAM}$ application rate in location A while the reductions were $26 \%$ and $33 \%$ for the same treatments in location B.

Large amounts of eroded soil were produced at the $5^{\text {th }}$ and $6^{\text {th }}$ measurements expressed as sharp increase in soil erosion as shown in Figure 5. Stable structure help soil particles to stay undisturbed and their ability to erode depend on the shear stress associated with running water. This means increasing the amount and velocity of running water would increase the ability of soil particles to erode. The large amount of rainfall occurred immediately before the $5^{\text {th }}$ and $6^{\text {th }}$ measurements could be the reason behind the sharp increase in soil erosion at the $5^{\text {th }}$ and $6^{\text {th }}$ measurements as indicated in Figure 5. Mohamadi and Kavian (2015) stated that increasing rainfall intensity yielded the highest runoff, sediment concentration and soil loss.

\section{Conclusions}

The main purpose of this study was to investigate the effect of three tillage practices and the effect of polyacrylamide application rate on surface runoff and erosion of sandy loam soils differ in silt and clay contents. The runoff results show that the CT1 and CT2 reduced runoff in both locations compared with that of the NT treatment. The CT2 had higher reduction in runoff compared to the CT1. PAM worked as a cohesive material to join the soil particle after ploughing such that the addition of PAM in both locations decreased runoff. The erosion results show that the highest eroded soil was in the CT1 treatment followed by the NT treatment and least in the CT2 treatment, respectively. The addition of PAM to the soil surface always reduced soil erosion in both locations. Higher application rates of PAM always resulted in less soil erosion. It can be concluded from the results obtained that the best PAM amounts to apply is 20 $\mathrm{kg} \mathrm{ha}{ }^{-1}$. The findings support the hypothetical concept that sustainable rain-fed agriculture is better achieved under farming practices that are carefully designed in accordance with soil type.

\section{Acknowledgement}

This project was funded by the King Abdulaziz City for Science and Technology (KACST) at Riyadh, Saudi Arabia under grant no. (At-35-220). The authors, therefore, acknowledge with thanks (KACST) for technical and financial support.

\section{References}

Alvaro-Fuentes, J., J.L. Arrue and C. Cantero-Martines. 2008. Aggregate breakdown during tillage in a Mediterranean loamy soil. Soil and Tillage Research 101: 62-68.

Baudron, F., J.A. Andersson, M. Corbeels and K.E. Giller. 2012. Failing to yield? Ploughs, conservation agriculture and the problem of agricultural intensification: an example from the Zambezi valley, Zimbabawe. Journal of Development Studies 48: 393412.

Benham, C.D., M.J. Gunthorpe and J.B. Davis. 2003. TRPV channels as temperature sensors. Cell Calcium 33: 479 $-487$.

Bhattacharyya, T., D.K. Pal, S. Lal, P. Chandran and S.K. Ray. 2006. Formation and persistence of Mollisols on zeolitic Deccan basalt of humid tropical India. Geoderma 136: 609-620.

Bjorneberg, D.L. and J.K. Aase. 2000. Multiple polyacrylamide applications for controlling sprinkler irrigation runoff and erosion. Applied Engineering in Agriculture 16: 501-504.

Bodhinayake, W. and B.C. Si. 2004. Near-saturated surface soil hydraulic properties under different land uses in the St Denis National Wildlife Area Saskatchewan, Canada. Hydrological Processes 18: 2835-2850.

Conant, R.T., M.G. Ryan, G.I. Agren, H.E. Birge, E.A. Davidson, P.E. Eliasson, S.E. Evans, S.D. Frey, C.P. Giardina and F.M. Hopkins. 2011. Temperature and soil organic matter decomposition rates-synthesis of current knowledge and a way forward. Global Change Biology 17: 3392-3404.

Coquet, Y., P. Vachier and C. Labat. 2005. Vertical variation of near-saturated hydraulic conductivity in three soil profiles. Geoderma 126: 181-191.

da Costa, C.H.M. and C.A.C. Crusciol. 2016. Long-term effects of lime and phosphogypsum application on tropicalno-till soybean-oat-sorghum rotation and soil chemical properties. European Journal of Agronomy 74: 119-132.

Daraghmeh, O.A., J.R. Jensen and C.T. Petersen. 2009. Soil structure stability under conventional and reduced tillage in a sandy loam. Geoderma 150: 64-71.

Das, A., R. Lal, D. Patel, R. Idapuganti, J. Layek, S. Ngachan, P. Ghosh, J. Bordoloi and M. Kumar. 2014. Effects of tillage and biomass on soil quality and productivity of lowland rice cultivation by small scale farmers in North Eastern India. Soil and Tillage Research 143: 50-58. 
Durr, C., J. Guerif, J.M. Machet, G. Recous and J. Estrade. 2001. A review of till effects on crop residue management, seedbed conditions and seedling establishment. Soil and Tillage Research 61: 13-32.

El Atta, H.A., I.M. Aref, T. Alshahrani, A. Alazba and K.A. Ibrahim. 2013. Comparative efficiency of rainwater harvesting by some types of microcatchments. International Journal of Plant, Animal and Environmental Sciences 3: 181-192.

El-Nakhlawy, F. S. 2010. Experimental Design and Analysis in Scientific Research. Scientific Publication Center, King Abdulaziz University, Jeddah, Saudi Arabia.

Fuentes, M., B. Govaerts, F. De León, C. Hidalgo, L. Dendooven, K.D. Sayre and J. Etchevers. 2009. Fourteen years of applying zero and conventional tillage, crop rotation and residue management systems and its effect on physical and chemical soil quality. European Journal of Agronomy 30: 228-237.

Gozubuyuk, Z., U. Sahinb, I. Ozturkc, A. Celik and M.C. Adiguzel. 2014. Tillage effects on certain physical and hydraulic properties of a loamy soil under a crop rotation in a semi-arid region with a cool climate. Catena 118: 195-205.

Graber, E.R., P. Fine and G.J. Levy. 2006. Soil stabilization in semiarid and arid land agriculture. Journal of Materials in Civil Engineering 18(2): 190-205.

Green, V.S. and D.E. Stott. 2001. Polyacrylamide: A review of the use, effectiveness, and cost of a soil erosion control amendment. In: Stott DE, Mohtar RH and Steinhardt GC (eds), Selected papers from the 10th International Soil Conservation Organization Meeting held May 24-29, 1999. Sustaining the Global Farm, pp. 384-389.

Green, V.S., D.E. Stott, J.G. Graveel and L.D. Norton. 2004. Stability analysis of soil aggregates treated with anionic polyacrylamides of different molecular formulations. Soil Science 169: 573-581.

Kahlon, M.S., R. Lal and M. Ann-Varughese. 2013. Twenty two years of tillage and mulching impacts on soil physical characteristics and carbon sequestration in Central Ohio. Soil and Tillage Research 126: 151-158.

Kuotsu, K., A.R. Das Lal, G. Munda, P. Ghosh and S. Ngachan. 2014. Land forming and tillage effects on soil properties and productivity of rainfed groundnut (Arachis hypogaea L.)-rapeseed (Brassica campestris L.) cropping system in northeastern India. Soil and Tillage Research 142: 15-24.

Lee, S.S., G.J. Gantzer, A.L. Thompson and S.H. Anderson. 2010. Polyacrylamide and gypsum amendments for erosion and runoff control on two soil series. Journal of Soil and Water Conservation 65: 233-242.
Lee, S.S., H.S. Shah, Y.M. Awad, S. Kumar and Y.S. Ok. 2015. Synergy effects of biochar and polyacrylamide on plants growth and soil erosion control. Environmental Earth Sciences 4: 2463-2473.

Lentz, R.D. and D.L. Bjorneberg. 2003. Polyacrylamide and straw residue effects on irrigation furrow erosion and infiltration. Journal of Soil and Water Conservation 58(5): 312-319.

Linhua, W., N. Dalabay, P. Lu and F. Wu. 2017. Effects of tillage practices and slope on runoff and erosion of soil from the Loess Plateau, China, subjected to simulated rainfall. Soil and Tillage Research 166: 147-156.

Mamedov, A.I., L.E. Wagner, C. Huang, L.D. Norton and G.J. Levy. 2010. Polyacrylamide Effects on Aggregate and Structure Stability of Soils with Different Clay Mineralogy. Soil Science Society of America Journal 74: 1720-1732.

McLaughlin, R.A. and N. Bartholomew. 2007. Soil factors influencing suspended sediment flocculation by polyacrylamide. Soil Science Society of America Journal 71: 537-544.

Mohamadi, M.A. and A. Kavian. 2015. Effects of rainfall patterns on runoff and soil erosion in field plots. International Soil and Water Conservation Research 3: 273-281.

Moraes, J.C., L. Seguy, F. Tivet, R. Lal, S. Bouzinac, P.R. Borszowskei, C. Briedis, J.B. Santos, D.C. Hartman, C.G. Bertoloni, J. Rosa and T. Friedrich. 2013. Carbon depletion by plowing and its restoration by no-till cropping systems in oxisols of subtropical and tropical agro-ecoregions in Brazil. Land Degradation and Development 26: 531-543.

Moret, D. and J.L. Arrúe. 2007. Dynamics of soil hydraulic properties during fallow as affected by tillage. Soil and Tillage Research 96: 103-113.

Morris, N.L., P.C.H. Miller, J.H. Orsen and R.J. Fraud Williams. 2010. The adoption of noninversion tillage system in United Kingdom and the agronomic impact on soil, crops and environment - a review. Soil and Tillage Research 108: 1-15.

Ngigi, S.N., J. Rockström and H.H.G. Savenije. 2006. Assessment of rainwater retention in agricultural land and crop yield increase due to conservation tillage in Ewaso Ng'iro river basin, Kenya. Physics and Chemistry of the Earth 31: 910-918.

Palm, C., H. Blanco-Canqui, F. DeClerck, L. Gatere and P. Grace. 2013. Conservation agriculture and ecosystems services: an overview. Agriculture, Ecosystems \& Environment 187: 87-105.

Petersen, A.L., A.M. Thompson, C.A. Baxter, J.M. Norman and A. Roa-Espinosa. 2007. A New polyacrylamide (PAM) formulation for reducing erosion and 
phosphorus loss in rainfed agriculture. Transactions of the ASABE 50: 2091-2101.

Pittelkow, C.M., X. Liang, B.A. Linquist, K.J. van Groenigen, J. Lee, M.E. Lundy, N. van Gestel, J. Six, R.T. Venterea and C. Van Kessel. 2014. Productivity limits and potentials of the principles of conservation agriculture. Nature 517: 365-368.

Rockström, J., M. Kaumbutho, P. Mwalley, J. Nzabi, A.W. Temesgen, M. Mawenya, L. Barron, J. Mutua and J.S. Damsgaard-Larsen. 2009. Conservation farming strategies in East and Southern Africa: yields and rain water productivity from on-farm action research. Soil and Tillage Research 103: 23-32.

Salem, H.M., C. Valero, M.A. Muñoz, M.G. Rodríguez and L.L. Silva. 2015. Short-term effects of four tillage practices on soil physical properties, soil water potential, and maize yield. Geoderma 237-238: 60-70.

SAS, 2006. SAS Institute Inc., Cary Nc., USA (Soft Ware Statistical Program).

Shekhawat, K., S.S. Rathore, B.K. Kandpal, O.P. Premi, D. Singh and B.S. Chauhan. 2016. Crop establishment techniques affect productivity, sustainability, and soil health under mustard-based cropping systems of Indian semi-arid regions. Soil and Tillage Research 158: 137146.

Shukla, M.K., R. Lal, L.B. Owens and P. Unkefer. 2003. Land use and management impacts on structure and infiltration characteristics of soils in the North Appalachian region of Ohio. Soil Science 168 (3): 167177.

Smith, D.R., E.A. Warnemuende, C. Huang and G.C. Heathman. 2007. How does the first year tilling a longterm no-tillage field impact soluble nutrient losses in runoff? Soil and Tillage Research 95: 11-18.
Sojka, R.E., D.L. Bjorneberg, J.A. Entry, R.D. Lentz and W.J. Orts. 2007. Polyacrylamide in agriculture and environmental land management. Advances in Agronomy 92: 75-162.

Sojka, R.E., J.A. Entry and J.J. Fuhrmann. 2006. The influence of high application rates of polyacrylamide on microbial metabolic potential in an agricultural soil. Applied Soil Ecology 32: 243-252.

VanWie, J.B., J.C. Adam and J.L. Ullman. 2013. Conservation tillage in dryland agriculture impacts watershed hydrology. Journal of Hydrology 483: 2638.

Yu, J., T. Lei, I. Shainberg, A. Mamedov and G. Levy. 2003. Infiltration and Erosion in Soils Treated with Dry PAM and Gypsum. Soil Science Society of America Journal 67: 630-636.

Yu, Y.W., T.J. Chen, C.J. Hong, H.M. Chen and S.J. Tsai. 2003. Association study of the interleukin-1 beta (C511T) genetic polymorphism with major depressive disorder, associated symptomatology, and antidepressant response. Neuropsychopharmacology 28: 1182-1185.

Zhang, Z., L. Lin, Y. Wang and X. Peng. 2016. Temporal change in soil macropores measured using tension infiltrometer under different land uses and slope positions in subtropical China. Journal of Soils and Sediments 16: 854-863. 